\title{
衛星画像データ分類用 MLP モデルの学習率の設定
}

\author{
Determination of Learning Rate in MLP Model \\ Used for Classification of Satellite Image Data
}

\author{
張＼cjkstart立 堅*, 星 \\ 仰** \\ Lijian ZHANG, Takashi HOSHI
}

\begin{abstract}
The multi-layer perceptron type artificial neural network model (MLP model) has been applied as a classifier in various classification fields, including remote sensing application. The back-propagation learning algorithm is widely employed in the MLP model as a simple learning algorithm. This algorithm, however, may lead to an unstable state of learning process, or take a lot of learning time in the learning process, if the learning rate is selected improperly. In this paper, a new learning rate institution equation is proposed for selecting of proper learning rate when the MLP model is employed in the classification of remote sensing satellite image data. At this time, a large scale training set is usually employed for learning of MLP model. Using the proposed institution equation, the learning rate is able to be directly determined by the training set size (number of training samples) and the network size (number of nodes). At the same time, it guarantees that the learning process of MLP model is convergent. The proposed learning rate institution equation is more practical than conventional institution equations. The latter is often accompanied with a number of experiments, to obtain a proper learning rate. Using the proposed learning rate institution equation, not only a faster convergence is yielded but also a smaller error is obtained. To inspect the efficiency of proposed equation, two different size training sets are learned by two different MLP models respectively for the classification of multispectral image data.
\end{abstract}

\section{1.はじめに}

多層パーセプトロン型ニューラルネットワークモデ ル（以下，MLPモデルと略称する）および改良した MLP モデルは, リモートセンシング分野において, 教 師付き分類の一種として，土地被覆物の認識・分類な どに効果的に応用されてきている1-7)。MLP モデルは 多くのトレーニングパターンサンプルを学習し, 学習 されるパターンを連想的に記憶し，その内容を一般化

* 茨城大学大学院工学研究科 Graduate School of Engineering, Ibaraki University. 4-12-1 Naka-narusawa, Hitachi, Ibaraki.

** 茨城大学工学部情報工学科 Dept. of Computer and Information Sciences, Faculty of Engineering, Ibaraki University. 4-12-1 Naka-narusawa, Hitachi, Ibaraki.

「写真測量とリモートセンシング」Vol. 35，No. 1， 1996
してパターン認識抢よび分類できる能力がある。また， MLP モデルは，各ニューロン (ノード) 間の結合重み を調整することによって最適な分類クラスの判別関数 を求めることができる。結合重みの調整はMLPモデ ルの学習と呼ばれ，その調整の過程は MLP モデルの 学習過程と呼ばれる。学習にはいくつかの方法があり, その中の代表的な方法としてパックプロパゲーション 学習法 (以下, $\mathrm{BP}$ 学習法と略称する) がある8)。しか し, この方法は学習速度が遅いため, 学習に長時間を 要する。

学習速度は多種な要素の影響をうける。重要な要素 の一つは学習率 $\eta$ と呼ばれるパラメータである ${ }^{8,9) 。 こ ~}$ のパラメー夕は, 学習過程が形成されるかどうかを決 定するもので，BP 学習法を利用する前に適切に選択 しておかなければならない。学習率 $\eta$ の選択が適切で ない場合には, 学習過程が振動したり, 処理が遅くなつ たり, 収束できない状態になる。学習率設定法として, 学習率を学習過程で適切に調整して行く方法（以下, 
学習率適応調整法と略称する）と, 全学習過程におい て一定値を設定する方法（以下，学習率固定法と略称 する）がある。学習率適応調整法では, 全学習過程で 学習率がシステム誤差に伴って変化する変数としてい る。この方法では, 学習率はシステム評価関数（シス テム誤差関数ともいう）の状況に応じて調整されるた め, 学習速度が速いという利点がある ${ }^{10) 。 し か し, ~ こ の ~}$ 方法は計算が煩雑なため，大規模なトレーニングパ ターンデータセット（以下，トレーニングセットと略 称する）には適用しにくい。一方, 学習率固定法は, 学習率の設定が簡単にでき，大規模なトレーニング セットにも直接適用できる。通常の BP 学習法をリ モートセンシング画像データ分類のために用いると き，トレーニングセットは大規模となるので，学習率 固定法がよく用いられる ${ }^{11)}$ 。

本論文では，学習率固定法に基づいて，適切な学習 率の設定を試みる。まず，土地被覆物の認識・分類に 利用される MLP モデルについての重要なパラメータ である学習率 $\eta$ の設定について論述し, 実用的な新し い学習率設定式を提案する。また，提案する学習率を 用いて, 実験デー夕を解析し, 学習率の適性を調べる。 ここでは，2 個のトレーニングセットを用いて学習を 行った 2 個の異なる構成の MLP モデルを取り上げ, MOS-1衛星の MESSR 画像デー夕を分類して，提案 する学習率の実用性を検討する。そして, 本研究で得 られた成果を結論で述べる。

\section{MLP モデルと BP 学習法}

\subsection{MLP モデル}

MLP モデルは，ニューラルネットワークモデルの 一種であり，パターン分類・認識分野でよく用いられ

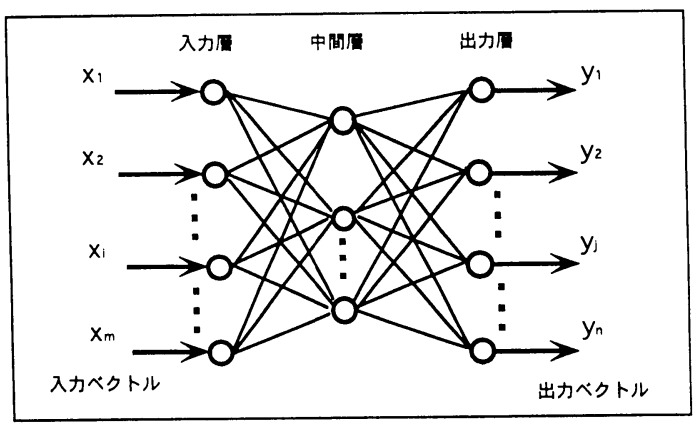

図 1 MLPモデルの一般構造
ている。ネットワークの基本素子ニューロン（あるい はノード）が階層的に配置され，各層は適当な数の ニューロンを保有し，それらのニューロンは重みつき で相互結合されている。一般的な形状は，図 1 のよう に隣接した層のノードのみを結合したものである。 データをネットワークに与える層は入力層と呼ばれ る。それとは反対側の層を出力層といい，中間にある 層は中間層と呼ばれている。図 1 は中間層が一つの 3 層 MLP モデルを示している。

各層の入力データと出力デー夕は，それぞれベクト ルの形式で表現される。入力ベクトルIは，ある層の各 ノードに同時に入力されるデー夕を組み合わせて, 式 (1)として表現される。

$$
\mathrm{I}=\left\{\mathrm{i}_{1}, \mathrm{i}_{2}, \cdots, \mathrm{i}_{1}, \cdots, \mathrm{i}_{\mathrm{m}}\right\}
$$

ここで, $\mathrm{m}$ はこの層のノード数である。

出力ベクトル $\mathrm{O}$ は，ある層の各ノ一ドに対して，同 時に出力する出力デー夕を組み合わせて, 式(2)として 表現される。

$$
\mathrm{O}=\left\{\mathrm{o}_{1}, \mathrm{o}_{2}, \cdots, \mathrm{o}_{\mathrm{j}}, \cdots, \mathrm{o}_{\mathrm{m}}\right\}
$$

このうち, 教師信号としての出力ベクトルは, 式(3)で 定義される。

$$
\mathrm{T}=\left\{\mathrm{t}_{1}, \mathrm{t}_{2}, \cdots, \mathrm{t}_{\mathrm{j}}, \cdots, \mathrm{t}_{\mathrm{n}}\right\}
$$

ここで, $\mathrm{n}$ は出力層のノード数である。

入力層を除く, MLP モデルの各層のノードは, 図 2 に示すように 2 つの機能を保有している：前層のノー ドの出力を集約し，自分自身の出力を準備する。その ため第 $\mathrm{j}$ 層（入力層を除く）の各ノードの入力と出力

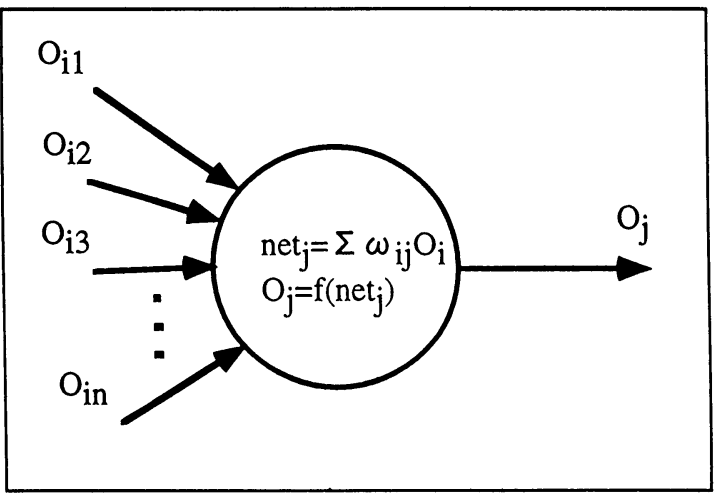

図 2 ノード内部の機能 
は, 式(4), (5)に示すように入力ベクトル $\mathrm{I}_{\mathrm{j}}$ と出力ベクト ル $\mathrm{O}_{\mathrm{j}}$ で表現される。

$\mathrm{I}_{\mathrm{j}}=\sum \mathrm{w}_{\mathrm{ij}} \mathrm{O}_{\mathrm{i}}$

$\mathrm{O}_{\mathrm{j}}=\mathrm{f}\left(\mathrm{I}_{\mathrm{j}}\right)=1 /\left(1+\exp \left(-\mathrm{I}_{\mathrm{j}}\right)\right)$

ここで,

$\mathrm{I}_{\mathrm{j}}:$ 第 $\mathrm{j}$ 層のノードの入力ベクトル

$\mathrm{w}_{\mathrm{ij}}$ ：第 $\mathrm{i}$ 層と第 $\mathrm{j}$ 層の各ノードの間の結合重みの

$\mathrm{n} \times \mathrm{m}$ 行列, $\mathrm{n}$ は第 $\mathrm{i}$ 層のノード数, $\mathrm{m}$ は第 $\mathrm{j}$ 層の ノード数

$\mathrm{O}_{\mathrm{i}}$ : 第 $\mathrm{i}$ 層のノードの出力ベクトル

$\mathrm{O}_{\mathrm{j}}$ : 第 $\mathrm{j}$ 層のノードの出力ベクトル

$\mathrm{f}:$ : ドの出力関数

入力層 (第 0 層) におけて, 各ノードの入力と出力

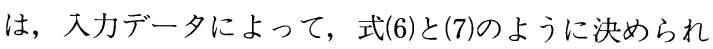
る。

$\mathrm{I}_{0}=\mathrm{X}$

$\mathrm{O}_{0}=\mathrm{I}_{0}$

ここで,

$\mathrm{I}_{0}:$ 入力層の入力ベクトル

$\mathrm{X}$ ：同時に入力するデー夕を組み合わせて形成する パターンベクトル

$\mathrm{O}_{0}$ ：入力層の出力ベクトル

\subsection{BP 学習法}

$\mathrm{BP}$ 学習法は MLP モデルで用いられる学習法の 1 種である。この学習法はネットワークの教師信号の出 力と実際の出力の差 (誤差) と, ノードへの入力信号 の積に比例して, ネットワーク内の各ノードを結合す る重みを修正して，入力パターンの分類クラスの判別 関数を学習する。学習過程はトレーニングセット中の トレーニングパターンサンプルを用いて, 要求される 出力にもっとも近い出力を得るために, 各ノード間を 結合する重みを調整する過程である。 BP 学習法は容 易にMLP モデルに適用できる。この学習則には最小 二乗誤差法を用いて, 出力層ノードの実際の出力ベク トル $\mathrm{O}$ と教師信号の出力ベクトル $\mathrm{T}$ 間の誤差二乗和 を減少させる非線形最適化問題となる。つまり, 学習 の目的はモデルの各層のノード間を結合させる重み $\mathrm{W}_{\mathrm{ij}}$ を調整して, 下記の䛊差評価関数を最小化して, 教 師信号の出力ベクトル Tを学習する。
$\mathrm{E}=-\frac{1}{2} \Sigma\left(\mathrm{T}^{\mathrm{p}}-\mathrm{O}^{\mathrm{p}}\right)^{2}$

ここで,

$\mathrm{E}$ ：すべてのトレーニングデー夕に対して実際の出 カベクトル O と教師信号の出力ベクトル T の間 の䛊差

$\mathrm{T}^{\mathrm{p}}: \mathrm{p}$ 番目入力トレーニングデータに対して出力層 の教師信号の出力ベクトル

$\mathrm{O}^{\mathrm{p}}: \mathrm{p}$ 番目入力トレーニングデータに対して出力層 の実際の出力ベクトル

学習する過程は, トレーニングデー夕を 1 個ずつ入 力するごとに結合重みを調整する逐次修正法と, 卜 レーニングデータそれぞれに対する䛊差から求める結 合重みの調整量を加算し，トレーニングデータ全体に ついて加算された調整量で結合重みを調整する一括修 正法の 2 種類がある。一括修正法には，重みの修正回 数が少なくなるために学習時間を短縮できるという効 果があり，よく用いられる。

一括修正法の学習する過程は, 全体のトレーニング データを学習して終了するまで，下記の更新規則に よって繰り返される。

$\Delta \mathrm{w}_{\mathrm{ij}}(\mathrm{n}+1)=\eta \delta_{\mathrm{i}}^{\mathrm{p}} \mathrm{O}_{\mathrm{i}}^{\mathrm{p}}+\alpha \Delta \mathrm{w}_{\mathrm{ij}}(\mathrm{n})$

ここで,

$\delta_{1}^{\mathrm{p}}: \mathrm{p}$ 番目のトレーニングデー夕に対して第 $\mathrm{i}$ 層の ノードにおける誤差

$\mathrm{O}_{\mathrm{i}}^{\mathrm{p}} \mathrm{p} \mathrm{p}$ 番目のトレーニングデータに対して第 $\mathrm{i}$ 層の ノードの出力ベクトル

$\eta$ : 学習率として設定されるパラメータ

$\alpha$ ：モーメント率として設定されるパラメータ

$\mathrm{p}$ 番目のトレーニングデータに対して, 出力層oの 各ノードを考察すると䛊差 $\delta_{0}{ }^{\mathrm{p}}$ は次式によって与えら れる：

$$
\delta_{0}{ }^{\mathrm{p}}=\left(\mathrm{T}_{\mathrm{o}}{ }^{\mathrm{p}}-\mathrm{O}_{\mathrm{o}}{ }^{\mathrm{p}}\right) \mathrm{O}_{0}{ }^{\mathrm{p}}\left(1-\mathrm{O}_{0}{ }^{\mathrm{p}}\right)
$$

中間層 $\mathrm{j}$ の誤差 $\delta_{\mathrm{j}}^{\mathrm{p}}$ は式(11)によって与えられる：

$\delta_{\mathrm{j}}^{\mathrm{p}}=\mathrm{O}_{\mathrm{i}}{ }^{\mathrm{p}}\left(1-\mathrm{O}_{\mathrm{i}}^{\mathrm{p}}\right) \sum \delta_{\mathrm{i}}^{\mathrm{p}} \mathrm{W}_{\mathrm{ij}}$

式(11)の中で和の部分は $\mathrm{i}(=\mathrm{j}-1)$ 層からの䛊差を含み, 他項は出力関数から導き出されるものである。

上記の学習過程によって, すべてのトレーニング データに対して, MLP モデルの学習誤差とこれらの 平均值は順次減少する。学習過程が形成されれば, 誤 
差は繰り返す学習回数が増すごとに減少する。最後に, ネットワーク内の結合の重みは安定し誤差が変化しな くなる。

\section{3 . 学習率の設定}

\section{1 従来の学習率設定式}

式(9)において，学習率 $\eta$ は任意に選択できるパラ メータである。これは学習する過程を決める重要なパ ラメータである。 $\eta$ を十分大きく選択すれば, 学習の速 度は速められる傾向を示すが，ネットワーク誤差が振 動してしまうと学習過程は収束しなくなってしまう可 能性がある。一方, $\eta$ を小さく選択すると, ネットワー ク誤差が振動してしまう可能性は小さくなるが学習速 度が遅くなる。そこで, 学習速度と学習過程の安定性 のバランスを保持するために, 適切な学習率を選択す ることが必要になってくる。このことに対して, D. E. RumelhartらはBP学習法を提案したとき，ネット ワークの全体ノード数を $\mathrm{n}$ としき, 学習率 $\eta$ は $\mathrm{n} の$ 逆数とした ${ }^{[8]}$ 。

$$
\eta=1 / \mathrm{n}
$$

しかしながら，一括修正法に対して，学習率はネッ トワークのノード数 $\mathrm{n}$ と関係するだけでなく, トレー ニングデー夕数 $\mathrm{p}$ にも関係する。トレーニングデータ 数 $\mathrm{p}$ が増加すると, $\mathrm{BP}$ 学習法の誤差とその総和もそ れに伴い増加する。特に, MLP モデルをりモートセン シング画像デー夕の分類に用いる場合, トレーニング デー夕数は100以上になる。この原因によって，式(12)で 選定する学習率を用いる BP 学習法は不安定になる可 能性がある。この問題点に対して, P. D. Heermann ら は次の学習率を提案しだ)。

$$
\eta=\mathrm{C}_{0}(1 / \mathrm{p})(1 / \mathrm{n})
$$

ここで,

$$
\begin{aligned}
& \mathrm{p} \text { : トレーニングデータ数 } \\
& \mathrm{n} \text { : ネットワークの全体ノード数 } \\
& \mathrm{C}_{0} \text { : 経験によって決定する定数 }
\end{aligned}
$$

この学習率は D. E. Rumelhart らの提案した学習率に トレーニングデータ数 $\mathrm{p}$ を考慮に入れて，リモートセ ンシング画像デー夕分類のため一括修正法を用いる BP 学習法に適用している。しかし,トレーニングデー 夕数 $\mathrm{p}$ およ゙ネッッワークのノード数 $\mathrm{n}$ が変化する
とき,この学習率は定数 $\mathrm{C}_{0}$ も変化させなければならな いという問題が内在している。このため, 定数 $\mathrm{C}_{0}$ を決 定するために事前に多くの実験を必要とすることが筆 者らの研究で明らかになった。この点では, P. D. Heermann らの学習率にはまだ実用性に久ける面を 含んでいる。

\section{2 提案する学習率}

前節で述べたように，P. D. Heermann らが提案し た学習率（式(13)）は，事前に多くの実験を行って定数 $\mathrm{C}_{0}$ を決定する必要がある。そこで，ここではトレーニ ングセットのサイズ pの変化に伴って，P. D. Heer mann らの提案する学習率 $\eta$ がどのように変化するか を明示するために下記のような実験を行った。ネット ワーク全体のノード数 $\mathrm{n}=19$ (本論文で実画像への適 用の際に用いた MLP モデルの 1 種), $\mathrm{C}_{0}=7.0 \times 10^{3}$ を 選定したとき，トレーニングセットのサイズ $\mathrm{p}$ と式(13) で求められる学習率 $\eta$ との関係は四 3 のようになっ た。この図 3 から明らかなように, $\mathrm{p}<1,000$ とき， $\eta$ は 急速に収束し， p > 2, 000 とき， $\eta$ は収束状態となる。

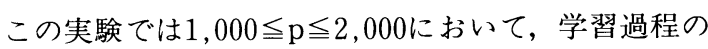
収束性が良好であった。しかしながら， $\mathrm{n}$ を変化させた とき，あらためて定数 $\mathrm{C}_{0}$ を選択しなければならない し, $\mathrm{C}_{0}$ の変化に伴って学習率 $\eta$ が収束するトレーニン グセットのサイズ $\mathrm{p}$ の範囲も変化してしまう。

そこで, 本研究では式(13)における $C_{0}$ を決定する実験 と $\mathrm{p}, \mathrm{n}$ の増大に伴う学習率への影響を滑らかにする ことを考え，まず $\mathrm{p}, \mathrm{n}$ については同一のロガリズム曲 線を当てはめた。これが式(14)である。式(14)は自然対数 であるが，常用対数にしても， $\mathrm{C}_{1}$ が約 5.3 分の 1 になる だけのため， $\mathrm{C}_{1}$ の值で十分対応できる見通しをたてて

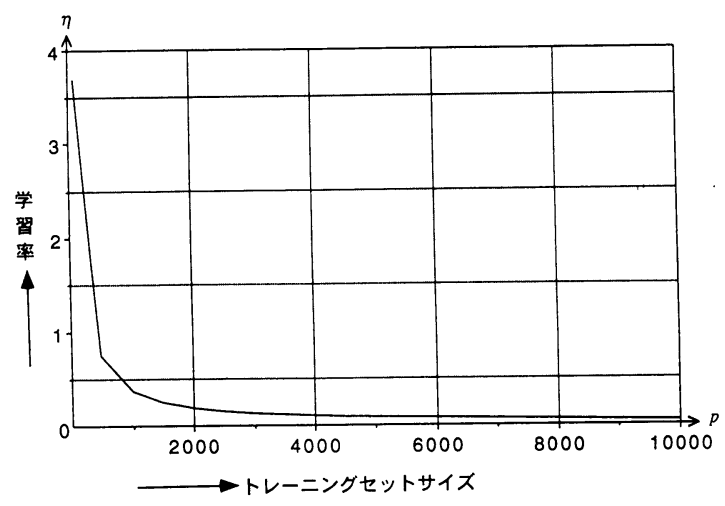

図 3 学習率とトレーニングセットサイズの関係 
いる。

$\eta=\mathrm{C}_{1}(1 / \operatorname{lnp})(1 / \operatorname{lnn}) \quad(\ln$ : 自然対数 $)$

(14)

図 4 は $\mathrm{n}=19$ において, $\mathrm{C}_{1}$ を 1 から 20 まで変化させた ときの $\mathrm{p}^{-} \eta$ 曲線を $\mathrm{C}_{1}=1,4,9$ み示したものである。 $\mathrm{C}_{1}=1$ のとき学習速度が遅く, $\mathrm{C}_{1}=9$ のとき学習過程にお いて誤差が振動状態を呈する。 $\mathrm{C}_{1}=4$ のときは学習過程 における誤差の振動が少なく安定しており，学習速度 の点から考えてもほぼ妥当な值であると考えられる。

以上のことから, 式(14)において $\mathrm{C}_{1}=4$ とする, 下記の 式(15)を経験式として提案する。

$$
\eta=4(1 / \operatorname{lnp})(1 / \operatorname{lnn})=(1 / \ln \sqrt{\mathrm{p}}) \cdot(1 / \ln \sqrt{\mathrm{n}})(15)
$$

\section{4 .学習率による誤差の収束実験とその結果}

$\mathrm{BP}$ 学習法の性能は多くの要素の影響を受ける。そ のため, いくつかの実験がネットワークの出力に関す る結果を得るため行われてきている。本研究は，学習 率 $\eta$ を設定するために関係するトレーニングデー夕 の数，モデルの構造などについて考察する。提案する 学習率の式(15)の実用性を確かめるために，3 層 MLP モデルとして MLP(4-12-3) モデル(以下 MLP モデル I とする）と MLP(4-48-8) モデル（以下 MLP モデル II とする）の 2 種類を取り上げ，各々にトレーニング セットをそれぞれ学習される。比較のために，従来提

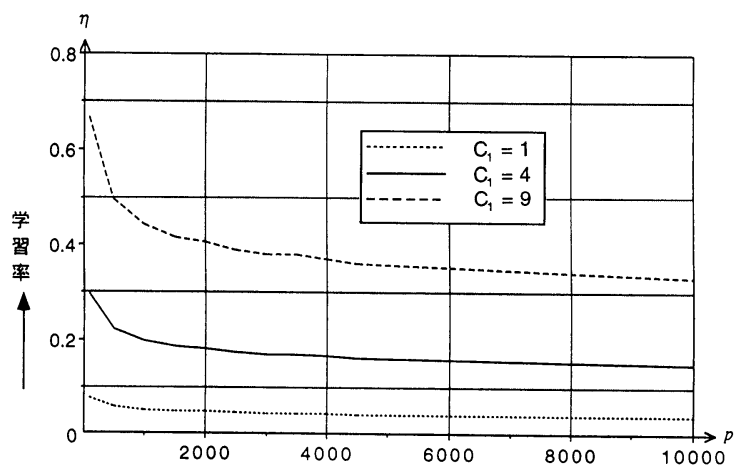

図 4 学習率係数の相違による学習率とトレーニングセッ トサイズの関係
案されている学習率を用いた学習も併せて行う。

\section{1 実験用画像データ}

実験デー夕は MOS-1衛星の MESSR 画像データで BSQ フォーマット形式のものである。困 5 はその内の バンド 4 (波長 : $0.80 \leqq \lambda \leqq 1.10 \mu \mathrm{m}$ ) の画像デー夕を 示す。解析対象地域は, 図 6 に示す北海道札幌市中心 のサブシーンで，約 $25.6 \mathrm{~km} \times 20.0 \mathrm{~km} \quad(512 \times 400$ pixels)の地域である。この地域内の主な土地被覆分類 項目は, 表- 1 に示すように, 水域 (海水と地面水), 市街地(高層ビル区)，住宅地，工場，裸地，草地と畑， 田, 樹林の 8 種類である。分類項目の数は出力層のノ一 ド数に対応して用意する。

\subsection{MLP モデルの構造}

3 層 MLP モデルは任意の複雑な分類問題に対して 十分解決できる手法として知られている ${ }^{8,9)}$ 。中間層の 数が増加すると計算の複雑性も増加する。本論文は 3 層 MLP モデルを用い，このモデルの入力層のノード の数は， 4 バンドの衛星画像をそれぞれに対応させ 4 個選んだ。すなわち，入力べクトル $\mathrm{I}=\left\{\mathrm{i}_{1}, \mathrm{i}_{2}, \mathrm{i}_{3}, \mathrm{i}_{4}\right\}$ となる。ここで, $\mathrm{i}_{\mathrm{j}}(\mathrm{j}=1,2,3,4)$ はシングルバンド の衛星画像デー夕である。出力層のノード数は, すべ て土地被覆分類項目に対応させて決定する。分類は表 1 に示す 8 項目について行い, 出力ベクトルと分類項 目との対応関係は表一 2 のように定義した。よって， 出力層のノード数は 3 個と 8 個に設定した。中間層の ノード数は，誤分類が少なくなるように，試行錯誤的 に決定し，出力層のノード数 3 個と 8 個に対応して, 12個と48個とする。以上のことをまとめると，本論文 で用いた MLP モデルは表ー 3 に示す 2 種類である。

\section{3 トレーニングデータセット}

本論文で提案した学習率の効果を調べるために，卜 レーニングデー夕数（トレーニングセットのサイズ） が1,700（トレーニングセット 1） と3,500（トレーニ ングセット 2 ) の 2 種類のトレーニングデータセット

表- 1 分類項目

\begin{tabular}{c|c|c|c|c|c|c|c|c}
\hline \hline No. & 1 & 2 & 3 & 4 & 5 & 6 & 7 & 8 \\
\hline 分類項目 & 水域 & 市街地 & 住宅地 & 工場 & 裸地 & $\begin{array}{c}\text { 草地 } \\
\text { 畑 }\end{array}$ & 田 & 樹林 \\
\hline \hline
\end{tabular}




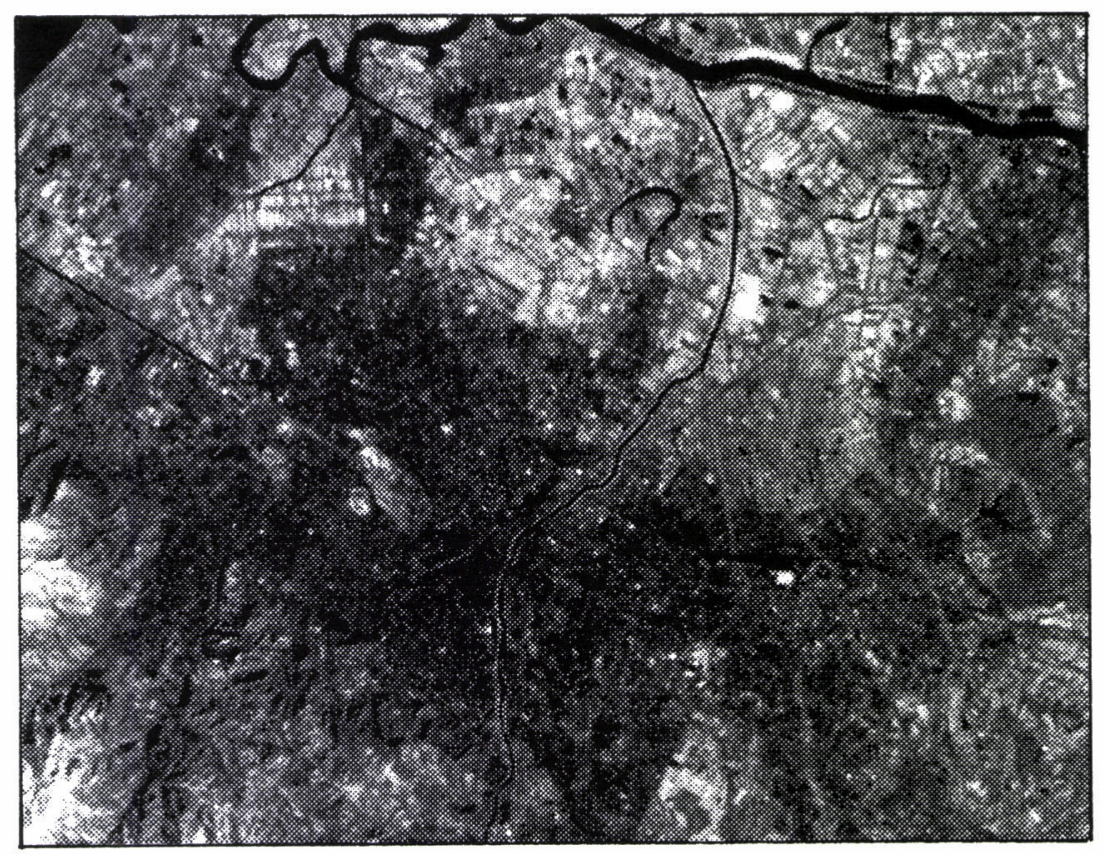

図 5 MOS-1 衛星MESSR画像データ (バンド 4)

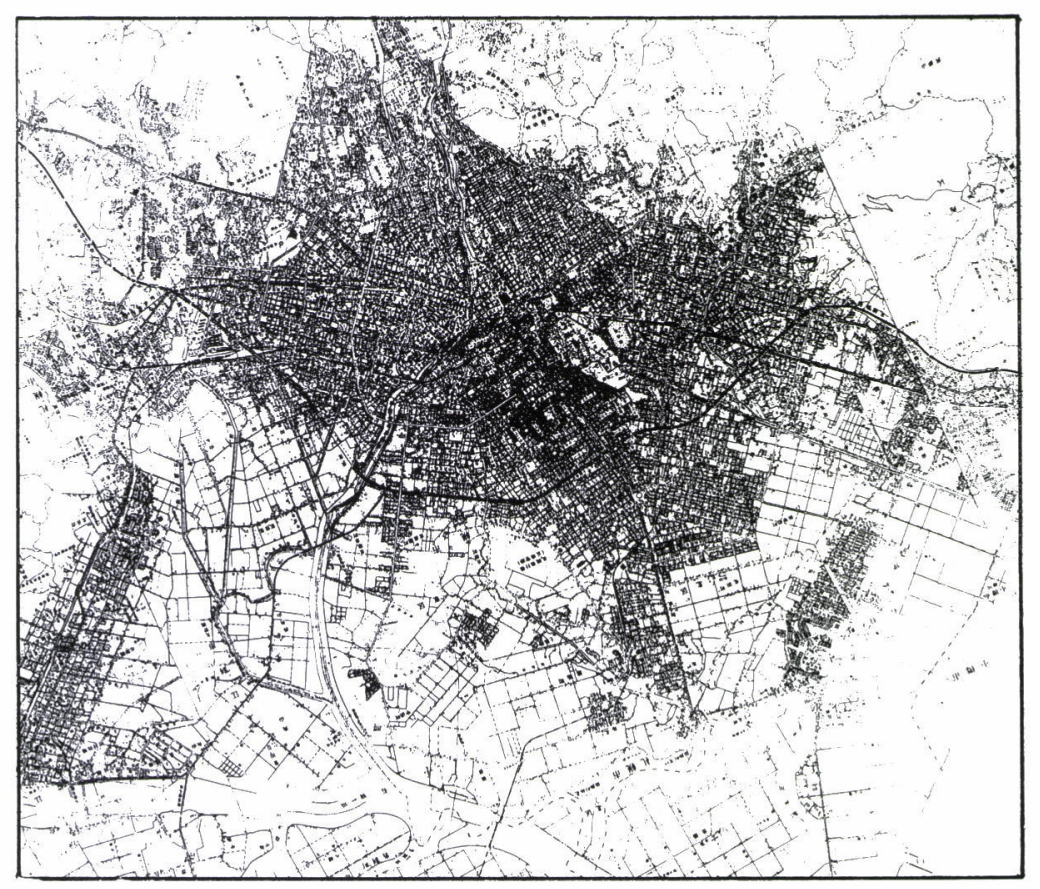

図 6 解析地域（北海道札幌市中心部） 
表一 2 出カコーデイング

\begin{tabular}{|c|c|c|c|c|c|c|c|c|c|c|c|}
\hline & \multicolumn{3}{|c|}{ MLP モデル I } & \multicolumn{8}{|c|}{ MLP モデル II } \\
\hline & 1 & 2 & 3 & 1 & 2 & 3 & 4 & 5 & 6 & 7 & 8 \\
\hline 水 域 & 0 & 0 & 0 & 1 & 0 & 0 & & 0 & & U & 0 \\
\hline 市街地 & 0 & 0 & 1 & 0 & 1 & 0 & 0 & 0 & 0 & 0 & 0 \\
\hline 住宅地 & 0 & 1 & 0 & 0 & 0 & 1 & 0 & 0 & U & 0 & 0 \\
\hline 工 場 & 0 & 1 & 1 & 0 & 0 & 0 & 1 & 0 & 0 & 0 & 0 \\
\hline 裸 地 & 1 & 0 & 0 & 0 & 0 & 0 & 0 & 1 & 0 & 0 & 0 \\
\hline 草地, 畑 & 1 & 0 & 1 & 0 & 0 & 0 & 0 & 0 & 1 & 0 & 0 \\
\hline 田 & 1 & 1 & 0 & 0 & 0 & 0 & 0 & 0 & 0 & 1 & 0 \\
\hline 樹 林 & 1 & 1 & 1 & 0 & 0 & 0 & 0 & 0 & 0 & 0 & 1 \\
\hline
\end{tabular}

表一 3 実験に用いる MLP モデル

\begin{tabular}{l|c|c|c}
\hline \hline & \multicolumn{3}{|c}{ ネットワークのノード数 } \\
\cline { 2 - 4 } & 入力層 & 中間層 & 出力層 \\
\hline MLP モデル I & 4 & 12 & 3 \\
\hline MLPモデル II & 4 & 48 & 8 \\
\hline \hline
\end{tabular}

を準備した。

\section{4 入カと出力}

MLP モデルの入力と出力は通常 $[0.0,1.0]$ の間に 限定される。一方, MESSR 衛星画像デー夕は $[0,255]$ の間の範囲にある。MLP モデルに適応させるために, 入力衛星画像デー夕はすべでMLP モデルの入力層の とりうる值の範囲に変換する。また, 式(5)より各ノ一 ドの出力が 0 や 1 を示すのは, それぞれ入力の荷重和

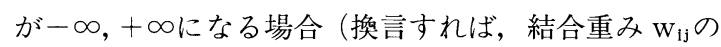

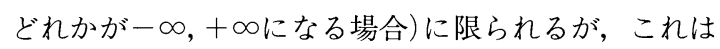
MLP モデルの性質上現実的ではないので，実際には ノードの出力は 0.1 あるい 0.9 に接近するとき学習の 目標に達成したことにする。

\section{5 収束実験と結果}

学習率の効果を調べるために, MLP モデル I と II を用いて筆者らの提案した学習率（式(15)）と P. D. Heermann らの提案した学習率（式(13)）をトレーニン グセット 1 と 2 に適用した。トレーニングセットのサ イズ $\mathrm{p}$ とネットークのサイズ $\mathrm{n}$ を種々変化させた ところ, 学習の収束状態に達することが確認された。
各 MLP モデルの各トレーニングにおいて誤差の変化 (学習曲線)を図 7 と図 8 に図示する。図 7 はトレー二 ングセット 1 と 2 に対して各学習率を適用した場合の MLP モデル I の学習曲線である。図 8 は同じ条件で の MLP モデルIIの学習曲線である。

図 7 （a）を観察すると，筆者らの学習率と P. D. Heermann らの学習率は概ね同じ様な学習曲線を示 してが，筆者らの学習率は学習の繰り返し回数 $\mathrm{N}$ が $\mathrm{N}<1,800$ のとき学習誤差が速く減少している。そのあ と学習誤差の変化も小さくなる。両学習率とも約 2,700 回の学習をさせると収束状態に達する。全般的に, 筆 者らの学習率の誤差は P. D. Heermann らの学習率の 誤差より $\Delta \mathrm{E} \fallingdotseq 0.1$ 以上小さい。

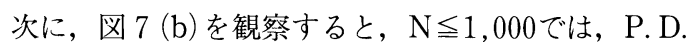
Heermann らの学習率は筆者らの学習率より誤差が 急速に減少している。しかし，このとき，収束状態に 達していないので，学習を続ける必要がある。N> 1,000 とき, 筆者らの学習率は P. D. Heermann らの 学習率より誤差が小さくなり, N>2,200で収束状態に 達する。P. D. Heermann らの学習率の学習過程は $\mathrm{N}>3,000$ で収束状態に達し, 筆者らの学習率とほぼ同 じ学習誤差となる。

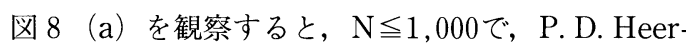
mann らの学習率による学習誤差は速く減少する。そ のあと, 筆者らの学習率を用いる学習過程の誤差は速 く減少する。 $\mathrm{N} \geqq 2,200$ で学習過程は $\mathrm{E} \fallingdotseq 0.2$ 学習誤 差で収束状態に達する。一方, P. D. Heermann らの 学習率の誤差は少しずつ減少し, $\mathrm{N} \geqq 3,500 て ゙$ 誤差 $\mathrm{E} \fallingdotseq$ 0.27 に収束してしまう。図 8 (b) の中に, 初期の学習 過程 $(\mathrm{N}<300)$ では, P. D. Heermann らの学習率が 筆者らの学習率より小さい学習誤差が得られるが，そ のあと筆者らの学習率を用いる学習誤差は急速に減少 し, $\mathrm{N} \geqq 2,300 て ゙ \mathrm{E} \fallingdotseq 0.22$ の学習誤差を持って収束す る。それに対して，P. D. Heermann らの学習率を用 いる学習過程は $\mathrm{N} \geqq 3,100 て ゙$ 䛊差 $\mathrm{E} \fallingdotseq 0.32$ に収束して しまう。

以上のことから，筆者らの学習率は P. D. Heermann らの学習率より良い学習速度と精度を持ってい るといえる。その上, 筆者らの学習率 (式(15)) を用い たとき, 学習率 $\eta$ の設定が簡単になる。得られた学習 率值は大きいサイズ $(\mathrm{p}>1,000)$ のトレーニングセッ 卜に対して適切な学習率といえる。筆者らが提案した 学習率 (式(15)）と P. D. Heermann らの提案した学習 


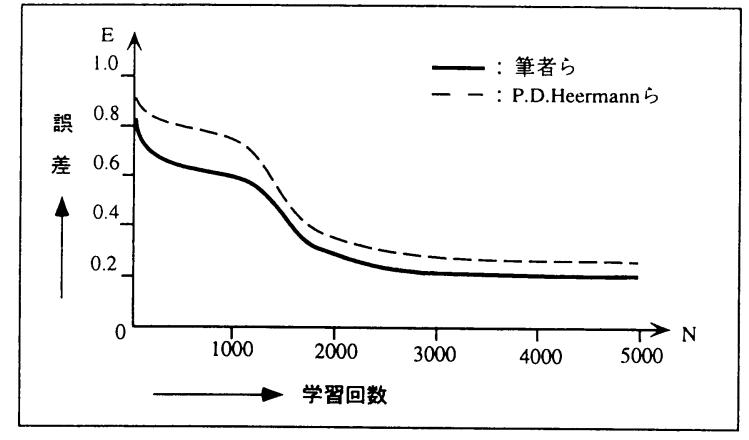

a) トレーニングセット 1

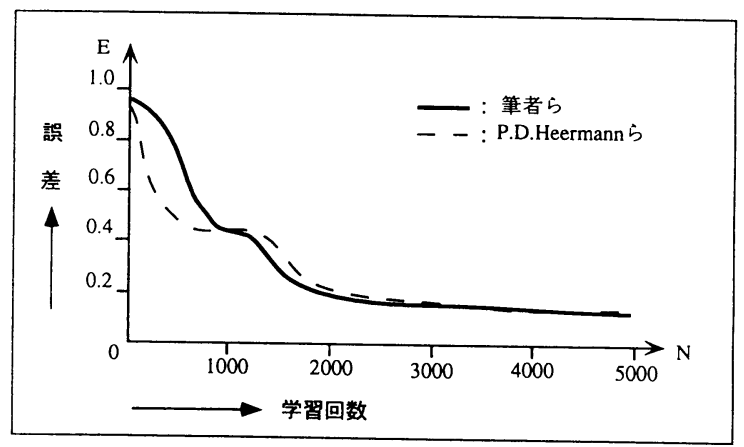

b) トレーニングセット 2

図 7 MLPモデルの学習曲線

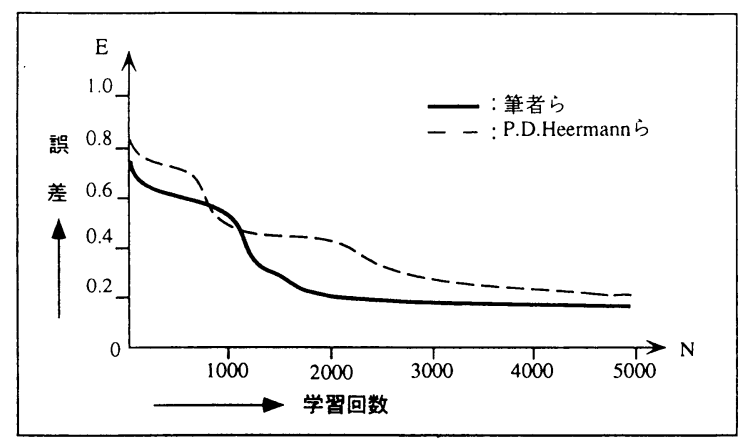

a) トレーニングセット 1

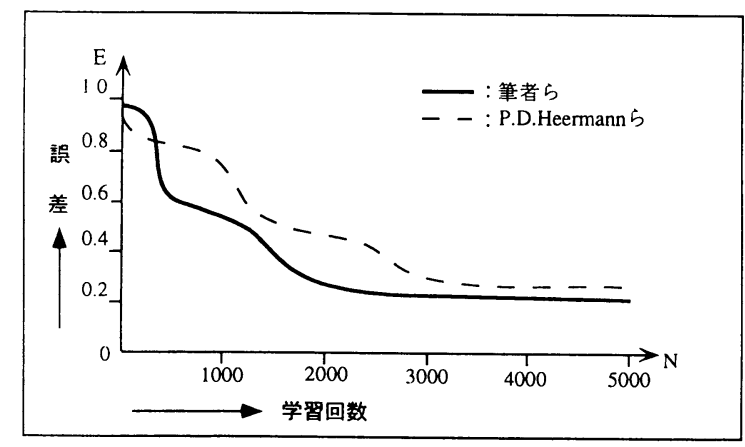

b) トレーニングセット 2

図 8 MLPモデルII学習曲線

表一4 各設定式を用いて収束状態に達するとき学習回数（学習速度）

a ) MLP モデル I

\begin{tabular}{c|c|c}
\hline \hline パターン数 & $\begin{array}{c}\text { P.D. Heermann らの } \\
\text { 提案式 }\end{array}$ & 筆者らの提案式 \\
\hline 1,700 & 2,700 & 2,700 \\
\hline 3,500 & 3,000 & 2,200 \\
\hline \hline
\end{tabular}

b ) MLP モデルII

\begin{tabular}{c|c|c}
\hline \hline パターン数 & $\begin{array}{c}\text { P.D. Heermann らの } \\
\text { 提案式 }\end{array}$ & 筆者らの提案式 \\
\hline 1,700 & 3,500 & 2,200 \\
\hline 3,500 & 3,100 & 2,300 \\
\hline
\end{tabular}

表一 5 各設定式を用いて収束状態に達するとき誤差総和（学習精度）
a ) MLP モデル I
b) MLP モデル II

\begin{tabular}{c|c|c}
\hline \hline パターン数 & $\begin{array}{c}\text { P.D. Heermann らの } \\
\text { 提案式 }\end{array}$ & 筆者らの提案式 \\
\hline 1,700 & 0.265 & 0.242 \\
\hline 3,500 & 0.189 & 0.185 \\
\hline \hline
\end{tabular}

\begin{tabular}{c|c|c}
\hline パターン数 & $\begin{array}{c}\text { P.D. Heermann らの } \\
\text { 提案式 }\end{array}$ & 筆者らの提案式 \\
\hline 1,700 & 0.272 & 0.201 \\
\hline 3,500 & 0.319 & 0.223 \\
\hline \hline
\end{tabular}


率（式(13)）を用いたときの，それぞれの学習速度（収 束状態に達するときの学習回数）と学習精度（収束状 態に達するときのシステム䛊差）を表一 4 と表一 5 に まとめた。この結果からも上記のことが裏付けられて いるといえる。

\section{5.おわりに}

MLP モデルの学習率 $\eta$ はモデルの速度を決定する 重要な要素である。一括修正法に対して学習率 $\eta$ は卜 レーニングセットのサイズ (サンプル数) p とネット ワークのサイズ(ネットワークのノード数) $\mathrm{n}$ の両方に 関係している。トレーニングセットの大きさおよびモ デルの構成が変化すれば，学習率もこれに応じて変化 させる必要がある。特に, MLP モデルはリモートセン シング画像デー夕の認識と分類に応用されるとき，一 般にトレーニングデー夕数とモデルの構成は解析地区 によって異なるため，これに相応する学習率をあらか じめ設定しなければならない。この場合，学習率は従 来 P. D. Heermann らの提案した学習率 (式(13))によっ て設定されてきている。この式中に経験的に決定する 定数 $\mathrm{C}_{0}$ が存在する。このため適切な学習率值を得るの に，多くの実験が必要とされる。本研究では，この煩 雑さを避けるために, 適切な学習率の設定を試み, そ の結果として学習率 $\eta$ を設定する経験式 (式(15)) の提 案を行った。この提案した経験式である学習率 $\eta$ は $\mathrm{p}$ とnのみの関数で表現され，P. D. Heermann らの提 案した学習率の係数を決定することができた。

さらに, 提案する学習率の実用性を検討するために, $\mathrm{p}$ の異なるサイズ $(\mathrm{p}>1,000)$ のトレーニングセット 2 種類とノード数 $\mathrm{n} の$ 異なる MLP モデル 2 種類に従来 法（P. D. Heermann らの方法）と筆者らの提案法を それぞれに適用して，MOS-1衛星の MESSR 画像 デー夕を分類した。その結果，筆者らの提案する学習 率を用いた方が, 従来の学習率より, 学習速度が速く, かつ学習精度も高いことをわかった。なお，学習率に 式(15)を用いる時は学習回数 N を 2,300 程度選定する必 要がある。

今後の研究課題としては提案されている各学習率は 経験式のため，すべての実験デー夕に適しているとい う保証ではないので理論的研究が必要である。筆者ら
の提案した学習率もこの面では同様の傾向にある。ま た， C $C_{0}$ 簡素化を目的としたため正整数しか与えて実 験していないので, さらに詳細な究明も必要である。 （受付日1995.6.21，受理日1996.1.11）

\section{参考文献}

1) J. A. Benediktsson, P. H. Swain, and O. K. Ersoy, (1990), "Neural Network Approaches Versus Statistical Methods in Classification of Multisource Remote Sensing Data", IEEE Trans. on Geosci. \& Remote Sensing, vol.28, pp.540-552.

2 ) 吉田知司, 大松 繁, 寺西 大, (1991), ”ニューラル ネットワークを用いたリモートセンシングデータのパ ターン認識”, システム制御情報学会論文誌, Vol.4, No.1, pp.11-20.

3 ) P. D. Heermann and N. Khozenie, (1992), "Classification of Multispectral Remote Sensing Data Using Back-Propagation Neural Network", IEEE Trans. on Geosci. \& Remote Sensing, vol. 30, pp.81-88.

4 ) H. Bischof, W. Schneider, and A. J. Pinz, (1992), " Multispectral Classification of Landsat Image Using Neural Network", IEEE Trans. on Geosci. \& Remote Sensing, vol.30, pp.482-490.

5 ) Y. Hara, R. G. Atkins, S. H. Yueh, R. T. Shin, and J. A. Kong, (1994), "Application of Neural Network to Radar Image Classification”, IEEE Trans. on Geosci. \& Remote Sensing, vol.32, pp.100-109.

6) L. Zhang and T. Hoshi, (1994), "A Fuzzy Neural Network Model (FNN Model) for Classification Using Landsat-TM Image Data”, International Geosci. and Remote Sensing Symp. Digest, pp.1845-1847.

7 ) L. Zhang, J. H. Tsuruta, and T. Hoshi, (1994), "An Expanded MLP Model for Classification of Satellite Image Data", Proceedings of the 15th Asian Conference on Remote Sensing, vol.2, pp.151-156.

8 ) D. E. Rumelhart and J. L. McClelland, Eds., (1986), Parallel Distributed Processing, vol. 1, Combridge, MA : MIT Press, Vol.1 pp.318-362.

9) Y. H. Pao, (1989), Adaptive Pattern Recognition And Neural Networks, Addison-Wesley Publishing Company, Inc., pp.117-125.

10）渡辺嘉二郎, 芹沢一雅, 候 麗雅, (1994), ”学習係数 の適応調整によるニューラルネットワーク学習の高速 化”, 計測自動制御学会論文集, Vol.30, No.9, pp. 1093-1099.

11）張 立堅，星 仰，(1994), ”パックプロパゲーション 学習法についての学習率の設定”, 日本写真測量学会平成 6 年度年次学術講演会発表論文集, A-3, pp.11-14. 